\title{
Jennifer Webb
}

\section{Multiple and contradictory interpellations: or, How to juggle cats}

Monday. It's nine a.m. I meant to get here early to beat the parking rush, but there were dishes to do, and laundry to hang out, and cats to feed, and it's our day for watering the garden. Now it's nine a.m, and there's no space anywhere near my building. Cars are circling the parking lots like lost birds. Never mind.

Nine a.m. on a Monday morning, and though I didn't leave the office yesterday - Sunday - till after six, there are already three messages on my voicemail, and there are forty-seven email messages of which:

6 offer me viagra

10 invite me to view hot sex online

3 urge me to purchase medications that are available online

2 promise me a $\mathrm{PhD}$

5 guarantee pre-approval of my mortgage

5 are about work; notices for or reminders of meetings

4 are jokes from friends and relations

1 is an informative memo from the $\mathrm{VC}^{\prime} \mathrm{s}$ office; something about this month's restructure. I'll read it later

4 are requests from potential students for information about the courses

3 are from current students, who need something from me: extensions, advice 4 - well, these don't fit any of the above categories; I'll call them 'other communications'.

It's Monday. I don't have to teach until tomorrow, but must finish writing my lecture. It's poetry, this semester, designed for third-year undergrads, many of whom are reluctant to write poems. V. intense.

It's Monday. I've brought in with me, on discs and CD-roms and in slippery bundles of paper, the work I did or meant to do over the weekend.

I've brought with me too the blistered fingers of a weekend gardener, the stiff legs of a weekend walker, the hot skin of a weekend swimmer, the slight buzz of a weekend drinker. And the stress of a Monday morning 
academic.

Never mind.

I delete the junk emails. Answer some of the emails that aren't junk. Try to write my lecture. And every few minutes it's Come in! Every few minutes it's Hello? Can I help you? All morning it's paper and people; all afternoon it's meetings I'd rather not attend; and in the interstices there are calls from students, colleagues, members of the community. The local college wants me to talk to their Year 12s about writing and being a writer. The local Society for the Blind wants me to talk to members about writing and being a writer - 'Oh, and could you judge our short story competition, please?' The local chapter of the FAW wants me to talk to them about writing for children, and being a children's writer (But I'm not a children's writer!... 'Oh? Doesn't matter. Just talk about whatever you like. Say something about children's writing'). I need to write that lecture. I need to prepare documents for the next meeting. I need to finish off my manuscript. I need to send an abstract to that conference that's being held in Sheffield in July next year. I need to go home and feed the cat.

This is what most of us academics experience all day: noise. It's so noisy I can't hear what's going on, so noisy I can find no order, no way out, no way of getting by. But surely there must be a way of managing this noise, this rush, this endless life? I'm a writer, and a researcher; I must be able to find some suggestions from those who've survived this, before me.

Maybe from Lotman who said:

Art - and here it manifests its structural kinship to life - is capable of transforming noise into information. It complicates its own structure owing to its correlation with its environment (in all other systems the clash with the environment can only lead to the fade-out of information)... [because art is].... particular type of play between redundant order and informative surprise. (1)

So art is akin to life? Okay; that makes sense: art is life-like because it oscillates between order and surprise. Noise becomes information at the point at which order meets surprise.

Yes, okay. Let me think about that for a few days.

Tuesday. It's 9:45 am, and thanks to telephone-related distractions I'm already 15 minutes late for the meeting of the Divisional Research Institute but I'm not really concerned, I didn't really want to be there, it's not as significant as it sounds.

Significant sounds - that's Aristotle's term for words when they're put to work in meaningful phrases, as compared with the sounds that simply make up words, or connect words. (2) This is the matter in which writers deal too: a system of sounds; and more particularly, a system by which sounds come to be significant. But what Aristotle didn't point out is that in this notion of signs and sounds and significance is, necessarily, noise - all that discord, struggle and slippage - because if all words organised into phrases are significant sounds, then what is it makes one sound more significant than another. What is it that allows a word or phrase to signify $\mathrm{X}$ and not $\mathrm{Y}$ ? What allows that same $\mathrm{X}$ to mean, in a way that has effects, 
while little Y languishes insignificantly on the benches? (Tampa vs Tammy, for instance.)

Writers, teachers of writing, and thinkers about writing must always at some level be engaged with this question; be engaged with the struggle of and for meaning and its value, and with the significance of sounds. As such, we're inevitably going to be caught up in the multiplicity of meaning, in the contradictory world of communication and creation. Inevitably; because, like Giorgio Agamben writes in his book Stanzas, 'The symbolic, the act of recognition that reunites what is divided, is also the diabolic that continually transgresses and exposes the truth of this knowledge'. (3) Inevitably; because, reuniting and transgressing, we must always be caught between symbol and diabol(ic). And, hence, necessarily struggling, necessarily stressed, while the words themselves, the meanings themselves, struggle to be heard.

This is something many of us ignore, most of the time. Most of the time, we treat meaning as transparent, as something we simply do; but as we also know, that's never really the case. Language is motivated, and it's arbitrary. Language is culture: not nature, but the 'second nature' in which we have become so much at home that we've forgotten how very odd it is, how removed it is (and, by implication, we are) from the 'first world' of things. Only when there's a glitch of some sort - cultural, temporal, translation - are we reminded of just how opaque and unlikely language really is ('Boy those French', says Steve Martin, 'They have a different word for everything!'). Only at this sort of point does the 'forgotten' - the fact that language isn't natural or inevitable - return to disturb any traces of complacency, and to reinsert noise into our experiences of language (and, hence, of the world).

Wednesday. My consultation time today is from ten to twelve. It's 9:30 now, so I have half an hour before students will begin to stream into my office with their queries and requests. In that half hour I thought I'd prepare for my talk to the Society for the Blind, but the computer's stuffing up again. It keeps freezing on me, or going into its Hal mode: 'I don't think you want to do that, Dave.' I can't get the technicians to take my complaints seriously because it always works just fine for them. Who'd have thought I'd need to know about programming to work in this job?

I struggle away with the computer, and in the interstices when it actually wakes up for twenty minutes at a time, I get some ideas down in concrete form. In my room, the students come and go. The phone rings, and rings, and rings. Then it's noon, lunch eaten as unobtrusively as possible while a $\mathrm{PhD}$ student presents a seminar on the effects of globalisation on a Third World community. I make notes while she speaks. The notes read: Must get that grant application in on time. Must write up the minutes from Research Committee meeting. Must check out the rumour that Executive is considering restructuring the Writing program. Wonder what's on at the movies tonight.

I really should be paying much closer attention; I'm one of her examiners; I'm going to have to respond to her material. So, stop. Switch off. Switch on again, tuned to a new channel. I can do it, I'm sure, can balance it all teaching, postgrad supervision, management, committees, community service, research, and yes, sometimes, my own writing; and yes, on good days, my own life. But most days, it feels like I'm juggling cats. 
The juggling of cats, people tell me, is an ancient but cruel tradition, another example of species arrogance by human beings - we don't juggle babies, after all. This accusation (or nomination) of species arrogance distresses me a little, as I toss and catch, toss and catch, and nurse the lacerations that run down my arm because you can't juggle cats without a bit of pain, and you have to juggle them anyway because demands are made on all of us to achieve impossible results across an impossible range of fields. If only I had a wife, and a secretary, and a gardener, and a copy editor; if only I had more time. If only I had my father's professional life, thirty years ago, when all he had to be was an executive, and on weekends a husband and father. And while his work was cripplingly demanding, he had a bevy of secretaries and clerks and wife and gardener to carry much of the load, so he could focus, and plough through the work (a bit like juggling very heavy hacky sacks, which might be weighty, but don't scratch). His identity, in other words - in neomarxist words - was interpellated across a restricted range of fields. For me, however, and for all of us here and now, interpellation is multiple, and across contradictory positions.

The word 'interpellation' comes, of course, from Louis Althusser who (before he went on to strangle his wife) described identity as something formed through the material conditions of ideology. His example goes like this: someone knocks at the door. I say, 'Is it you?' and when they say 'Yes' and open the door, la, it is 'you'. The one named 'you' has identified himself or herself as a distinct individual, cut out of the herd of possible 'yous', arrested by the pronoun. Because interpellation is all about naming ('inter[a]pellation' - named within [a system]) and recognising that name, and all the things that go with it: especially the constitution of subjectivity, the realisation of the 'me' that has a social role and function. Althusser explains this in his famous essay, 'Ideology and Ideological State Apparatuses'. 'Ideology', he writes, 'is a "representation" of the Imaginary Relationship of Individuals to their Real conditions of existence.' (If the reality is too awful, ideology will reframe it so you can cope, or feel you can cope.) This is a 'real' thing in itself, of course, however imaginary might be the relations it constructs. As Althusser goes on to point out in his second thesis, 'Ideology has a material existence' - material in that it produces us, constitutes us, calls us into being for particular purposes, and 'enlists' us into systems of belief and hence of practice. (4)

What does this mean, in effect? For me, it means I am inter[a]pellated (named, called into being, enlisted) as an academic, because it says so on my contract of employment, people refer to me as an academic, I believe I am an academic; I do academic work, when someone says, 'Hey, an academic', I say Are you talking to me?

It means I am named a writer (because it says so on my $\mathrm{CV}$, and on lists of the works I've published; people refer to me as a writer). I believe I am a writer. I do writerly work.

And it means I am named 'mother'; it says so on my family tree, and in the letters sent to me by people I call my children. When I hear someone call Mum, I turn around. I believe I am a mother. I do motherly work. And so on.

All the work that I do and the roles I fulfil are done and fulfilled in the (my) belief that there is a concrete and necessary relation between the name of that work or role, and the function it identifies. In short, I am interpellated by the social system in which I am; and at the moment I respond to the processes of naming, I am enlisted into a particular form of 
identity, and the practices that go with it. I am seized by - Althusser would say - ideology; I am seized by - I would say - the system in which I'm living and all its discourses and practices. I am subject to nomination: sounds that have significance, in relation to other sounds, in the sentence that comprises my life.

In the relation of belonging this creates, I am claimed. I am a me only in relation to others; I am a me only when I take up a subject position, at a point of time and in a point of space, and fulfil the roles it lays out. But this is not as easy as it sounds, because the interpellations that form me are all contradictory, and what this means is choice: if I'm this, then I'm not that. It's the basic economic principle: opportunity costs weighed (sometimes), suffered (always).

Which brings me back to Althusser, and the neomarxists who follow him, for whom society is not just noisy and confusing and distressing, but is also structured always in terms of antagonisms. For them, sounds are not simply significant; rather, they're empty in and of themselves. Any significance they hold emerges out of a struggle between the various meanings that might have been possible. Sounds mean, sounds are significant, when and because someone in a position of authority says so. So too, we can never just be; we can never just take the ways we are named as possessing a transparent meaning. Instead, we are made to mean, variously and often contradictorily; and because of the multiplicity involved, our subjectivity under one discourse is negated by another discourse. (5)

But that's not the only story; we aren't simply emptied and filled like washing bowls, at the whim of social authority or functional moments. We are also things that think [Descartes]; we are also self-organising systems [Maturana]; we are also, and always, contingent, in a process of change, in a state of becoming.

Friday. First up, School Board: two hours of argument, policy and chitchat. Then a flat run to the library, to catch that book I've had on hold before it gets sent back to the shelves and it'll be weeks before it's available again.

Meantime my new manuscript is ready to go to the publishers, it just needs a little more tinkering. Meantime my brother and his partner have had a baby and I must buy presents and send flowers. Meantime there's another rally I must attend to protest US interventions in Iraq (and elsewhere). Meantime the kitchen cupboards are empty, and we're subsisting on wine, cheese and crackers (a novel, and rather appealing, approach to malnutrition). Meantime there's a new poetry journal starting up, and I should sort through my stuff and find something to submit...I think I can. I think I can.

I am a something that thinks. I think. Therefore I am. But I am not a processor, unlike my computer which is still not working properly but if it were I could say of it, 'This is a something that processes'. People have tangles, not ordered pathways; we have multiple stories, contradictory realities; we live enmeshed in mazes of networks, rather than in the tidiness or linearity of binary logic.

So my life is inevitably chaotic, my head is necessarily full of stuff, and everything tends to noise rather than to significance; but this need not be 
the problem I perceive. The physicists assure us that there is order in chaos, or that order emerges out of chaos; that it looks chaotic because our systems are complex, but complexity means not poorly ordered, but information rich. (6) This is something worth thinking (about); if I rename my situation as rich in information, rather than as chaotic noise, will I feel better about it? Will I work better within it?

Saturday. I hope to spend no more than eight hours at work this weekend; and I hope to find, in this intersection of neomarxism and physical science, some way out of the problem of all this noise.

In fact, there are probably several ways out. One is the Brave Sir Robin approach (aka the pomo mode): run away! Escape the contradications and tensions and impossibilities in which we are necessarily enmeshed! Deleuze and Guattari say, if you know the territories in which you're functioning, if you know them really well, you can find escape routes: 'Find your black holes and white walls, know them, know your faces; it is the only way you will be able to dismantle them and draw your lines of flight.' (7)

The second escape is the put-up-with-it approach (aka the Marxist mode). This one goes: we are interpellated into positions from which there is virtually no hope of escape, because we are netted by language and structure. So adjust your expectations, and remember it won't go on forever - you'll be dead soon; or maybe there'll be a revolution.

Then there's a third, and I think more productive approach, Certeau's approach: escape while staying in place. We can do this if we make a point of engaging with meaning, with the significance of sounds, with the nominological work of ideology as it interpellates us into impossible and incompatible relativities. We can do this if we hold in confident knowledge the fact that this is how the physical universe works - we are not living in an aberrant moment; the lived experience is (always) one of noise, 'rich information', aka chaos.

Check out what the scientists are saying. Stewart and Cohen write that we human beings can cope with all that the universe and our own social organisation can throw at us. The proof that we can cope is that we are here. Moreover, they say, complexity can actually give us advantages not found in simple situations, because out of complexity come emergent phenomena: ways of bending or breaking what appeared to be rock-solid rules, and hence new ways of interacting with, living within, our chaos. (8)

Joseph Tabbi agrees. Noise, he suggests, is the very mechanism of consciousness which drives 'the constant adjustment between mental and material structurations'. (9) In other words, we aren't just body, or just mind, or just soul, or just ideologically constituted subjectivity; we are all these things and more, all to-ing and fro-ing between mental and material structurations, between conditions and considerations economic, neurotic, physiological, familial, intellectual, sexual, political and so on. All these things, all making different demands on us; but all open to adjustment through the cognitive function of the self. Cognition, in these terms, being not a Cartesian but a biological phenomenon, information-processing rather than solipsism, a feature possessed by every living thing that is embodied, in an environment, and capable of some quality of interaction. Whether we're people or plants, we are working cognitively, thinking in our human or plantly way, because this is what living things do. Even 
amoebae exist in and adapt to their environments in a way that must surely be instructive for those of us being turned into vegetables by the sheer stress of juggling commitments (aka cats).

Maturana and Varela call this autopoiesis: 'a way of establishing and maintaining a system's boundary by selecting meaningful elements (distinctions the system can use) out of an otherwise indistinct, "noisy," environment'. (10) Like plants, we humans can - in the sense of having the biological capacity - select out of the noise about us only those things that are meaningful at a particular moment. So we're not radically different from plants and amoeba in how we function; because like them we are physiological systems, subject to physical laws and conditions, and living in an unstable physical biosphere that is full of noise, full of chaos; and in that chaos and all its noise are hidden 'deep structures of order'. (11) The noise we hear is always there but we can tune it out as we seek those structures of order the scientists have assured us are there; as we engage in the to and fro of ourselves in our environments; as we engage in the struggle for meaning. Sure it's messy. Sure it looks chaotic and yet, the scientists tell us, it is all happening in predicable ways. As we - like all living creatures - orient ourselves to the ever-adjusting environment, we can make things happen; we can shape our own identity, practices and inner worlds out of the jumble and cacophony that surrounds us.

I feel a little like Polyanna now. After all, nothing's changed. It's Saturday, and I'm still at work, and it seems unlikely that I'll ever catch up. I'm still interpellated into multiple, and contradictory positions; still juggling cats. But what is encouraging about this is that the very conditions of meaningmaking - that is, it is slippery, contestatory, impossible to achieve with finality, always noisy, often contradictory - all these conditions increase uncertainty and by doing so they necessarily deepen and widen the meaning-making potential of any exchange, any sound, any situation. All this noise, that is, 'can lead to the emergence of new levels of meaning neither predictable from linguistic and genre conventions nor subject to authorial mastery'. (12) It is in the noise and often distress of chaos that we are formed and form ourselves. And since this is the condition of life, and is what differentiates me from my computer (though we both keep stalling), chaos and multiplicity is something humans can embrace. So I won't take it too seriously - since no moment is, as far as I'm aware, the final or the most significant - but instead will listen for the quiet order lying within the chaos. And, in the interests of keeping my job, my writing, my family, my commitment as a member of the community, my ability to have a bit of fun from time to time, I'll try out this new way of escape: an escape without leaving, an escape that is embedded in the assurance that built-in cognitive processes will allow me to thrive - or at least survive - in chaos; and be assured that order and art emerge from the morass.

\section{Notes}

1. Jurij Lotman. The Structure of the Artistic Text. Trans. Gail Lenhoff and Ronald Vroon. Ann Arbor: Michigan Slavic Materials, 1977, p. 75. Return to article

\section{Aristotle. The Poetics. Part 20. Trans. S. H. Butcher. Return to article}

3. Giorgio Agamben. Stanzas: Word and phantasm in Western culture. Trans. Ronald L. Martinez. Minneapolis: University of Minnesota Press, c1993, p. 136. Return to article 
4. Louis Althusser. 'Ideology and State Ideological Apparatuses (Notes towards an Investigation). In Slavoj Zizek (ed). Mapping Ideology. London \& New York: Verso, 1994, pp. 100-40. Return to article

5. Chantal Mouffe. 'Hegemony and New Political Subjects: Toward a new concept of democracy. Trans. Stanley Gray. In C. Nelson and L. Grossberg (eds). Marxism and the Interpretation of Culture. Urbana: U Illinois Press, 1988, pp. 89-104. Return to article

6. 'An important turning point in the science of chaos occurred when complex systems were conceptualized as systems rich in information rather than poor in order'. N. Katherine Hayles (ed). Introduction to Chaos and Order: Complex dynamics in literature and science. Chicago \& London: U Chicago Press, 1991, p. 6. Return to article

7. Gilles Deleuze and Félix Guattari. A Thousand Plateaus: Capitalism and Schizophrenia. Trans. Brian Massumi. Minneapolis \& London: U Minnesota Press, 1987, p. 188. Return to article

8. Ian Stewart and Jack Cohen. Figments of Reality: The evolution of the curious mind. Cambridge: Cambridge UP, 1997, pp. 73-75. Return to article

9. Joseph Tabbi. Cognitive Fictions. Minneapolis \& London: U Minnesota Press, 2002, p. 76. Return to article

10. Cited Tabbi, p. xxiii. Return to article

11. N. Katherine Hayles (ed). Introduction to Chaos and Order: Complex dynamics in literature and science. Chicago \& London: U Chicago Press, 1991, p. 1. Return to article

12. William Paulson. 'Literature, complexity, interdisciplinarity'. In N. Katherine Hayles (ed). Introduction to Chaos and Order: Complex dynamics in literature and science. Chicago \& London: U Chicago Press, 1991, pp.37-53 (p.45). Return to article

Dr Jennifer Webb is Program Director, Writing, in the School of Creative Communication at the University of Canberra. She also edits the Newsletter for the Australian Association of Writing Programs.

\section{TEXT}

Vol 8 No 1 April 2004

http://www.griffith.edu.au/school/art/text/

Editors: Nigel Krauth \& Tess Brady

Text@griffith.edu.au 